\title{
Rucho Is Right - But for the Wrong Reasons
}

Louis Michael Seidman

Georgetown University Law Center, seidman@law.georgetown.edu

This paper can be downloaded free of charge from:

https://scholarship.law.georgetown.edu/facpub/2313

https://ssrn.com/abstract=3715561

Forthcoming in University of Pennsylvania Journal of Constitutional Law.

This open-access article is brought to you by the Georgetown Law Library. Posted with permission of the author. Follow this and additional works at: https://scholarship.law.georgetown.edu/facpub

Part of the Constitutional Law Commons, and the Supreme Court of the United States Commons 


\section{Rucho Is Right - But for the Wrong Reasons}

\section{Louis Michael Seidman*}

In Rucho v. Common Cause, ${ }^{1}$ the Supreme Court ended its long struggle to formulate constitutional standards to regulate political gerrymandering by declaring that it was not up to the job. The Court held that it could come up with no manageable standards governing the controversy and that it therefore posed a nonjusticiable political question. ${ }^{2}$

In this brief comment, I attempt defend this outcome. The task is not easy, and I hope that the reader will at least give me some points for degree of difficulty. There is no denying that partisan gerrymandering is a very serious evil and there is no defending Chief Justice Roberts' dreadful opinion justifying the Court's refusal to do anything about it. Still, I argue, on balance, we are better off without the Supreme Court mucking around with this problem.

Moreover, the reasons why we are better off go beyond this particular issue and impeach some of the standard arguments for judicial intervention more generally.

I.

Before proceeding with the more general argument, a few words about why political gerrymandering poses a major problem and why the Court's explanation for its failure to deal with it is unconvincing.

A.

Partisan gerrymandering might be defined as the drawing of legislative district lines with the intent of producing a particular political outcome, usually the maximization of the political

Carmack Waterhouse Professor of Constitutional Law, Georgetown University Law Center.

139 S. Ct. 2484 (2020).

Id. at 2500 . 
strength of the gerrymandering party. In one form or another, it has been going on for as long as we have had a republic. ${ }^{3}$ At one time, the Supreme Court thought that it had mostly resolved the difficulty by requiring population equality in legislative districts, ${ }^{4}$ but it turns out that it was wrong. Indeed, in recent years, the problem has gotten much worse. By "packing" wasting votes by placing large numbers of extra disfavored voters in a single district - or "cracking" - wasting votes by dividing disfavored voters between districts so that they cannot form a majority anywhere - gerrymanderers can produce dramatically unfair results while still maintaining population equality among districts. ${ }^{5}$ By providing "safe" districts for favored candidates, gerrymanderers create an environment where the main obstacle to reelection is a primary challenge from the extreme factions of each party. ${ }^{6}$

Efforts to accomplish these outcomes used to be constrained by mutually accepted norms and by technical difficulties in predicting voter behavior and drawing the right lines. But in recent years, both obstacles have eroded. Politicians increasingly see themselves as involved

3 For example, although the word itself had not yet been coined, there is evidence that Patrick Henry was responsible for gerrymandering the congressional district in which James Madison was forced to run in 1788.. For detailed account, see Thomas Rogers Hunter, The First Gerrymander? Patrick Henry, James Madison, James Monroe, and Virginia's 1788 Congressional Districting, 9 Early Am. Stud 781 (2011).

$4 \quad$ See Reynolds v. Sims, 377 U.S. 533 (1964) (mandating population equality in state legislative districts); Westberry v. Sanders, 376 U.S. 526 (1964) (mandating population equality in congressional districts).

$5 \quad$ See, e.g., Pamela S. Karlan, Still Hazy after All These Years, 26 Cumb. L. Rev. 287, 289 (1995-96). For an argument that packing and cracking is not the optimal gerrymandering strategy, see Richard Holden, Voting and Elections: New Social Science Perspectives, 12 Ann. Rev. of Law \& Soc. Sci, 255, 259 (2016).

6 See, e.g., Daryl J. Levinson \& Richard H. Pildes, Separation of Parties, Not Powers, 119 Harv . L. Rev. 2311, 2335 (2006). 
in an existential struggle where even extreme measures are justified, ${ }^{7}$ and advances in computer science allow them to implement these extreme measures with clinical precision. ${ }^{8}$ Both parties have taken advantage of these changes, but, as it happens, Republicans have taken more advantage of them. ${ }^{9}$ The result is outcomes that are deeply unfair. For example, in the 2012 congressional election the Democrats won the overall popular vote, but the Republicans ended up with 33 more seats. ${ }^{10}$ A study of the 2018 election, which was a Democratic sweep, showed that Republicans won 16 more house seats than would be expected based on the average share of the vote in congressional districts. ${ }^{11}$ To make things still worse, districting is done by state legislatures, which are themselves badly gerrymandered in favor of Republicans. $^{12}$

These outcomes must be considered in the context of other changes that also erode the legitimacy of our political process. The Senate is grotesquely gerrymandered to favor Republicans. A vote for a Senator in Wyoming is 68 times more powerful than a vote for the a

7 For a discussion of political polarization and its impact on the willingness of politicians to play "hardball," see Michael J. Klarman, Foreword: The Degradation of American Democracy_and the Court, __ Harv. L. Rev. _ (2020) (forthcoming).

8 See Rucho v. Common Cause, 139 S. Ct. 2484, 2513 (2020) (Kagan, J., dissenting) (noting that changes in technology mean that make gerrymanders are "far more effective and durable than before, insulating politicians against all but the most titanic shifts in the political tides. These are not your grandfather's-let alone the Framers'-gerrymanders."

$9 \quad$ See Jed Handelsman Sugerman, Hardball vs. Beanball: Identifying Fundamentally Antidemocratic Tactics, 119 Col. J. Online 85, 116-17 (2019) (discussing Republican gerrymandering efforts).

10 See United States House of Representatives Elections, 2012, Ballotopedia, available at https://ballotpedia.org/United States House of Representatives elections, 2012.

11 See David A. Lieb, "GOP won more seats in 2018 than suggested by vote share "available at https://apnews.com/article/9fd72a4c1c5742aead977ee27815d776.

12 See Jed Handelsman Sugarman, note 9, supra, at 116-17. 
Senator in California. ${ }^{13}$ By 2040, two-thirds of Americans will control only thirty percent of the Senate. ${ }^{14}$

The outcome of presidential elections is similarly skewed. In 4 out of last 5 presidential elections, winner did not receive the majority of the popular vote and in 2 of last 5 , the loser received more votes than the winner. ${ }^{15}$

And then there is the Supreme Court itself. Republican presidents have appointed fifteen of the last ninteen justices to the Court ${ }^{16}$ even though they won the popular vote in only six of the last thirteen elections. ${ }^{17}$ The last Chief Justice of the United States appointed by a Democratic President was Fred Vinson, whose brief and undistinguished career ended more than sixty years ago. Before that, one has to go back to Edward White, who fought on the Confederate side in the Civil War. (Even White was nominated for Chief Justice by a Republican, but his initial appointment to the Court was by a Democrat). ${ }^{18}$ Given all these facts, it is no wonder that many Americans despair about the future of our democracy.

B.

13 For Wyoming and California population totals, see Countryeconomy.com "U.S. States Comparison: Wyoming vs. California," at https://countryeconomy.com/countries/usa-states/compare/wyoming/california. 14 See Philip Bump, "By 2040, two-thirds of Americans will be represented by 30 percent of the Senate," Wash. Post, Nov. 28, 2017, available at https://www.washingtonpost.com/news/politics/wp/2017/11/28/by-2040two-thirds-of-americans-will-be-represented-by-30-percent-of-the-senate/.

15 See Statista, "Share of electoral and popular votes for each winning candidate in all United States presidential elections from 1789 to 2016" available at https://www.statista.com/statistics/1034688/shareelectoral-popular-votes-each-president-since-1789/.

16 See Supreme Court of the United States "Justices 1789 to Present" available at https://www.supremecourt.gov/about/members text.aspx.

17 See Wikipedia, "United States Presidential Elections" available at https://en.wikipedia.org/wiki/United States presidential election.

18 See note 16, supra. 
The Supreme Court cannot be blamed for many of these problems and cannot be expected to fix them. But at least in theory, it could do something about partisan gerrymandering. Why hasn't it?

According to the Court, the Constitution's text provides no clear test by which to measure the constitutionality of various districting regimes. ${ }^{19}$ Of course, that is true, but it does not distinguish the partisan gerrymandering problem from virtually all other constitutional controversies that the Court regularly decides.

What the justices do for a living is to make up tests that are not in the Constitution. They have told us that content-based regulation of speech is subject to strict scrutiny, ${ }^{20}$ that racial classifications are justified only if they satisfy a compelling state interest and are narrowly tailored, ${ }^{21}$ and that that abortion regulations may not unduly burden a woman's right to choose. ${ }^{22}$ One searches the Constitution's text in vain for any of this. As even many constitutional originalists concede, nontextual construction of this sort is essential if the Court is to have any hope of actually applying constitutional values to the cases that come before it. ${ }^{23}$ It is true that partisan gerrymandering poses a special challenge because instances of it can be ranged along a continuum. As the Court points out, the Constitution commits the task

19 See Rucho, 139 S. Ct., at 2500 ("there are no legal standards discernible in the Constitution for making such judgments.")

20 See, e.g., Barr v. American Assn. of Political Consultants, 140 S. Ct. 2335, 2346 (2020) ("content based laws are subject to strict scrutiny").

21 See, e.g., Miller v. Johnson, 515 U.S. 900,904 (1995) (“Laws classifying citizens on the basis of race cannot be upheld unless they are narrowly tailored to achieving a compelling state interest.")

22 See Planned Parenthood of Southeastern Penn. v. Casey, 505 U.S. 833, 876 (1992) (O'Connor, Kennedy, \& Souter announcing the judgment) ("In our view, the undue burden standard is the appropriate means of reconciling the State's interest with the woman's constitutionally protected liberty.").

23 See, e.g., Lawrence B. Solum, 82 Ford. L. Rev. 453,458 (2013) ("the Construction Zone is ineliminable; the actual text of the U.S. Constitution contains general, abstract, and vague provisions that require constitutional construction for their application to concrete constitutional cases.") 
of legislative districting to the political branches. It is therefore close to inevitable that political considerations will play some role in the process. ${ }^{24}$ The question is how much of a role is too much?

Philosophers have a technical term for problems of this sort. They call it the Sorities Paradox. ${ }^{25}$ A collection of sand is either big enough or not big enough to constitute a "heap," but we can't specify precisely how many grains of sand make it a heap. People are either bald or not, but no one can say how many hairs a person must lose to achieve the dubious honor of baldness.

In cases like this, a line must be drawn somewhere, and any line will seem arbitrary. Does that mean that no line can be drawn? Clearly not. The Supreme Court has regularly used two strategies to confront the problem.

Sometimes, it announces a vague test and leaves the task of filling in the gaps to lower courts or to its own future cases. The Court has done this in the closely related context of racial gerrymandering. It has said that race-based districting is unconstitutional whenever it is so predominant a factor that the districting can only be explained as an effort to segregate voters. ${ }^{26}$ Similarly, it has announced that burdens on the abortion right are unconstitutional if

24 See Rucho, 139 S. Ct., at 2497 ("To hold that legislators cannot take partisan interests into account when drawing district lines would essentially countermand the Framers' decision to entrust districting to political entities.")

25 For a detailed description, see "Sorites Paradox," Stanford Encyclopedia of Philosophy, available at https://plato.stanford.edu/entries/sorites-paradox/.

26 See Shaw v. Reno, 509 U.S. 630, 646-47 (1993) (districting unconstitutional when "it rationally cannot be understood as anything other than an effort to 'segregat[e] voters' on the basis of race.") For a powerful attack on the Court's effort to distinguish between racial and partisan gerrymandering, see Girardeau Spann, Gerrymandering Justiciability, 108 Geo. L.J. 981 (2020). 
they are "undue." 27 Racial classifications violate the fourteenth amendment and content-based restrictions on speech violate the first amendment if they are not supported by a state interest that is "compelling." ${ }^{28}$ Regulation on the use of real property constitutes a taking if it "goes too far." ${ }^{29}$ It violates the due process clause for a judge to decide a case when one of the parties has made campaign contributions to the judge if the contributions lead to a "significant and disproportionate influence." 30

On other occasions, the court simply announces an arbitrary line. For example, in a closely related context, it has said that in state cases, the one person one vote standard is presumptively not violated if there is less than a 10 percent maximum deviation between districts. ${ }^{31}$ Similarly, the state interest in fetal protection changes at the point when the fetus is "viable." ${ }^{32}$ Even arch-originalist Antonin Scalia has resorted to arbitrary tests of this sort. How long does it take after a person is released from custody for an invocation of Miranda rights to wear off? Justice Scalia, writing for the Court announced that "[w]e think it appropriate to specify a period of time. . . It seems to us that period is 14 days." 33 How long can an arrested suspect be held without a probable cause determination? In County of Riverside v.

McLaughlin, ${ }^{34}$ the Supreme Court announced that the right answer was a presumptive forty-

27 See Planned Parenthood of Southeastern Penn. v. Casey, 505 U.S. 833, 876 (1992) (O’Connor, Kennedy, \& Souter announcing the judgment).

28 See Miller v. Johnson, 515 U.S. 900,904 (1995) (racial classifications); Barr v. American Assn. of Political Consultants, 140 S. Ct. 2335, 2346 (2020) (content-based restrictions).

29 Murr v. Wisconsin, 137 S. Ct. 1933, 1942 (2017).

$30 \quad$ Caperton v. A.T. Massey Coal Co., 556 U.S. 868, 884 (2009).

31 See Harris v. Arizona Ind. Redistricting Comn., 136 S. Ct. 1301, 1307 (2016) ("attacks on deviations under $10 \%$ will succeed only rarely, in unusual cases.")

32 See Planned Parenthood of Southeastern Penn. v. Casey, 505 U.S. 833, 870 (1992) (O'Connor, Kennedy \& Souter announcing the judgment of the Court) ("We conclude that the line should be drawn at viability, so that before that time the woman has a right to choose to terminate her pregnancy.")

$33 \quad$ Maryland v. Shatzer, 559 U.S. 98, 110 (2010).

$34 \quad 500$ U.S. 44 (1991). 
eight hour limit. ${ }^{35}$ Justice Scalia's dissent chastised the majority for ignoring "the clear dictates of the fourth amendment" and relying instead on "its own (quite irrefutable because entirely value laden) 'balancing' of the competing demands of the individual and the state." 36 He then announced that "[i]n my view, . . . it is an 'unreasonable seizure' within the meaning of the Fourth Amendment for the police, having arrested a suspect without a warrant, to delay a determination of probable cause for the arrest . . . beyond 24 hours after the arrest." 37

The Rucho Court had available to it both vague tests that might be made more precise over time and clear tests that are concededly arbitrary. Years ago, Justice White, writing for a plurality of the Court, suggested a test of the first type: partisan gerrymandering was unconstitutional when "the electoral system is arranged in a manner that will consistently degrade [a] group of voters'influence on the political process as a whole." 38 Similarly, Justice Kagan, dissenting in Rucho, argued that gerrymandering was illegal when it departed "too much" from the state's own neutral criteria for districting. ${ }^{39}$

A prominent test of the second type measures the "efficiency gap" defined as the ratio of "wasted votes" - the total number of votes cast for a losing candidate and votes over a bare majority cast for a winning candidate. ${ }^{40}$ How large an efficiency gap is too large? The leading

$35 \quad$ Id. at 56 ("We believe that a jurisdiction that provides judicial determinations of probable cause within 48 hours of arrest will, as a general matter, comply with the promptness requirement.")

$36 \quad$ Id. at 65 (Scalia, J., dissenting).

$37 \quad$ Id. at 70 (Scalia, J., dissenting).

38 Davis v. Bandemer, 478 U.S. 109, 132 (1986) (White, J. announcing judgment of the Court).

39 See Rucho, 139 S. Ct., at 2521 (Kagan, J., dissenting) ("this much is too much").

40 See Nicholas O. Stephanopoulos \& Eric M. McGhee, Partisan Gerrymandering and the Efficiency Gap, 82

U. Chi. L. Rev. 831, 834 (2015) (defining the "efficiency gap.") 
academic proponents of the test set the limit as changing the results for two seats in a state's House of Representatives delegation or eight percent of its state legislative delegation. ${ }^{41}$

Are these tests perfect? Of course not. If the Court insisted on perfect tests, it would never adjudicate constitutional claims. But like much of the rest of the Court's doctrinal innovations, the tests are good enough to be serviceable if the justices really wanted to do something about the problem.

II.

Why, then, should we be wary of a judicial solution? Chief Justice Roberts' opinion in Rucho is wrong in many ways, but it is right in one way: Political theorists, judges, and ordinary people are divided over what makes a system "democratic" and what counts as political "fairness." ${ }^{2}$ There is no consensus about how much protection for minorities is necessary in a democratic system and about which minorities to protect. We do not agree about the extent to which popular will should be filtered through a system that protects political elites from temporary frenzy. We have no shared understanding of whether proportional representation of politically salient groups is necessary for democratic legitimacy.

These disagreements translate into disagreement about what should count as unconstitutional political gerrymandering. Consider, for example, an effort to create fairness by drawing district lines so as to minimize the "efficiency gap" between parties. On the macrolevel, this districting produces a fair outcome. But on the micro-level, it creates what John Hart

\footnotetext{
$41 \quad$ Id. at 884.

42 See Rucho, 139 S. Ct., at 2500 ("The initial difficulty in settling on a 'clear, manageable and politically neutral' test for fairness is that it is not even clear what fairness looks like in this context.")
} 
Ely once referred to as "filler people." 43 These are voters who are deliberately stranded in districts where they have no chance of prevailing. Should these voters be satisfied with the fact that the state delegation, taken as a whole, fairly represents their interests? Or are they entitled to a fair chance of electing their own representative?

Similarly, what are we to make of "safe" districts? One might argue that a fair districting plan requires such districts so that a small majority in electoral preference on a state-wide basis does not produce a sweep for one party or the other. ${ }^{44}$ But safe districts also make it less likely that the representative will take some account of the interests of voters who chose her opponent. $^{45}$

Finally, how should we resolve the potential conflict between fairly representing the two political parties and fairly representing other salient groups, like racial or religious minorities? Suppose, for example, that in order to create a districting plan that fairly apportions power between Democrats and Republicans, it is necessary to provide disproportionately fewer seats likely to be captured by African Americans?

There is no obvious way to resolve to problems like these. To be consistent, a believer in democracy might say that disputes about political values should be resolved democratically. Unfortunately, though, disputes about what democracy entails cannot be settled democratically without first specifying the answer to the very question being debated.

$43 \quad J o h n$ Hart Ely, Standing To Challenge Pro-Minority Gerrymanders, 111 Harv. L. Rev. 576, 581-82 (1997).

44 See Davis v. Bandemer, 478 U.S. 109, 130 (1985) (White, J.) ("If all or most of the districts are competitive, ... even a narrow state-wide preference for either party would produce an overwhelming majority for the party in the state legislature.")

$45 \quad$ See, e.g., Richard Briffault, Definings the Constitutional Question in Partisan Gerrymandering, 14 Corn. J. L \& Pub. Pol. 397, 410 ("even the voters in the majority party may lose out if and when they are placed in districts engineered to provide the majority party a safe seat - just like voters in the minority party - the lack of competitiveness limits their ability to hold their representative accountable.") 
But while there are no good answers to the problems, there are some bad answers. An especially bad answer is turning the question over to nine unelected and unrepresentative judges who are part of an institution that has pretty consistently defended the most regressive forces in our society.

Suppose, then, that Rucco had come out the other way. Perhaps tests based on reducing the efficiency gap, on the state's own criteria for districting, or on the danger of permanently fencing out a political minority would improve the functioning of our democracy. But why should advocates for these tests believe that the Supreme Court would actually adopt them? It is easy to imagine other outcomes.

For example, there are more than a few hints in the Court's opinion that, were it to reach the merits, it would hold that partisan gerrymandering is constitutionally permissible. ${ }^{46}$ I do not claim that such a holding would mark a big change from where we are now, but it would certainly be a step in the wrong direction. It is one thing to say that gerrymandering poses a constitutional problem but that the Court cannot solve it. It would be another thing for the Court to give politicians constitutional permission to engage in the process.

Suppose that the Court held that partisan gerrymandering was unconstitutional and formulated its own test for dealing with it. Strikingly, in the years during which a plurality of the Court thought that it could adjudicate gerrymandering claims, the Court never actually invalidated a districting plan on these grounds. ${ }^{47}$ It is entirely predictable that the current

46 See, e.g., Rucho, 139 S. Ct., at 2495 ("The framers were aware of electoral districting problems and considered what to do about them. They settled on a characteristic approach, assigning the issue to the state legislatures, expressly checked and balanced by the Federal Congress.")

$47 \quad$ See id at 2497 (recounting Court's prior disposition of partisan gerrymandering cases). 
justices would develop a test that was so flabby that it would validate virtually any conceivable gerrymander.

Worse yet, the justices have made clear that they believe the right to vote is "individual" and has nothing to do with the fair representation of a group to which the voter belongs. ${ }^{48}$ It would be easy to build on this position to hold that efforts to fairly represent the political parties are actually unconstitutional. As explained above, ${ }^{49}$ these efforts inevitably create "filler people" who, as individuals, are deprived of a fair opportunity to elect representatives reflecting their interests. It is not hard to imagine that the current court would therefore hold that "nonpartisan" and "fair" districting is actually unconstitutional. ${ }^{50}$

Similarly, the current Court has already shown deep hostility toward efforts to provide proportional representation for racial minorities. ${ }^{51}$ A court empowered to end political gerrymandering might use that power to further dilute the voting strength of these groups in the name of protecting the voting strength of Democrats and Republicans.

The short of it, then, is that there is no good reason to believe that a decision treating partisan gerrymandering as posing a justiciable issue would make things better and many good reasons to think that it would make things worse.

Why, then, are liberal critics of the Court unanimously condemnatory of Rucho? Why are they insistent on giving people who share none of their constitutional commitments additional power?

48 See Gill v. Whitford, 136 S. Ct. 1916, 1931 (2018) (rejecting claim that citizen has constitutionally cognizable interest in overall composition of legislature independent of individual right to vote).

$49 \quad$ See text at note 41, supra.

50 Cf. Rucho, 139 S. Ct., at 2499 (ensuring "fair" share of seats to each party "comes at the expense of ... individuals in districts allocated to the opposing party."

$51 \quad$ See Shaw v. Reno, 590 U.S. 630 (1993) Miller v. Johnson, 515 U.S. 900 (1995). 
The answer, I think, is rooted in deeper pathologies in liberal constitutionalism pathologies that I explore in the next Part.

III.

Years ago, in his canonical if idiosyncratic defense of the Warren Court, John Hart Ely set out a paradigm for dealing with cases like partisan gerrymandering. Because the Court was a countermajoritarian institution, Ely thought that it had no business foisting its own values on the American people. For that reason, he vigorously opposed the Court's decision in Roe v. Wade, ${ }^{52}$ which, he thought, could only be justified by adopting contestable value judgments. ${ }^{53}$

But Ely thought that the Court still had an important role to play by ensuring that the political branches, which did make value choices, made them democratically. By focusing on the processes of democratic decision making, the Court could actually be representative reinforcing rather than democracy denying. Ely tried to justify most of the Warren Court's agenda on this theory. ${ }^{54}$ On this theory, partisan gerrymandering involves exactly the wrong issue on which the Court should stay its hand.

There are many problems with Ely's thesis, but for present purposes, it is important to focus on one of them - what might be labeled the "Ely Nonsequitur." It goes something like this:

Premise: The political system is undemocratic and unfair.

Conclusion: The Supreme Court should do something about the problem.

52410 U.S. 113 (1973).

53 See John Hart Ely, The Wages of Crying Wolf: A Comment on Roe v. Wade, 82 Yale L. J. 920 (1973).

$54 \quad$ See generally, John Hart Ely, Democracy and Distrust (1980). 
The conclusion follows from the premise only with an additional, undefended premise:

that the Supreme Court will make things better rather than worse. Depending on one's point of view, there are two problems with that premise, each of which independently dooms the syllogism.

From a "neutral" or objective" point of view, which changes make things better or worse is, itself, contestable. In our political culture, there is reasonable disagreement about the necessary conditions for democratic representation - disagreement that cannot be resolved without making value judgments that are, themselves, contestable. That fact returns us to the dilemma that is Ely's starting point - i.e., the illegitimacy of judicial value judgments.

From the situated point of view of the many progressives who criticize Ruccio, it should be obvious that judicial intervention will not solve our difficulties. Most progressives understand that we do not want this Supreme Court deciding what kinds of economic regulation violates substantive due process. They are increasingly coming to understand that we don't want this Supreme Court deciding what regulations of speech violate the First Amendment. They are wary of Supreme Court judgments about what kinds of accommodations are necessary to protect religious freedom. Why should they want this Supreme Court to formulating constitutionally mandatory requirements for political fairness?

As already noted, although Ely's theory has been influential, it is also idiosyncratic. But the "Ely Nonsequitur" is generalizable. All pleas for liberal activism are rooted in assumptions about the Supreme Court that have little grounding in our history and less grounding in our current reality. Maybe some time in the future, we will have a Supreme Court that we can trust to make us a more decent, inclusive, and equal nation, but we certainly do not have that Court 
now. And even if we did, constitutional liberals need to think hard about the desirability and durability of elitist, top-down reform that is not grounded in popular organizing and mobilization.

Years ago, the great legal iconoclast, Jerome Frank, wrote a book that exposed another nonsequitur that reenforces Ely's. ${ }^{55}$ It might be called the "Freudian Nonsequitur" and goes something like this:

Premise: Life is unfair and things suck.

Conclusion: Don't worry, Daddy will fix it.

At some point, most of us outgrow this comforting myth in other areas of life, but, despite Frank's efforts, it retains surprising vestigial strength within the liberal, legal professoriate. It therefore seems necessary to point out that, as with the Ely Nonsequitur, the premise is right, but the conclusion does not follow. Yes, the political process is unfair and undemocratic. Yes, it is stacked against progressive change. Yes, resort to it is always difficult and often futile. Still, the Supreme Court is not our daddy and it is not going to fix things.

Once we grow out of the Freudian Nonsequitur, we can begin to face the disappointing and dispiriting reality of the world we live in. As Freud famously said, we can then replace our neurotic misery with ordinary unhappiness. What that means in this context is embracing the truth: that as bad as the political process is, the only real alternative to acquiescing in injustice is organizing, voting, protesting, arguing, and resisting. The sooner that progressives learn that lesson, the better it will be for the country. 
